\title{
PENERAPAN MODEL KONSTRUKTIVIS-METAKOGNITIF PADA MATERI SISTEM KOORDINASI UNTUK MENINGKATKAN KEMAMPUAN BERPIKIR KRITIS SISWA KELAS XI MIA 1 SMA NEGERI 6 SURAKARTA TAHUN PELAJARAN 2015/2016
}

\author{
YUNITA NUR ANGGRAENI, BASKORO ADI PRAYITNO, JOKO ARIYANTO \\ Program Studi Pendidikan Biologi \\ Fakultas Keguruan dan Ilmu Pendidikan \\ Universitas Sebelas Maret \\ Jl. Ir. Sutami 36 A, Surakarta, 57126, Indonesia \\ *Corresponding Author: yunita_nura@yahoo.co.id
}

Manuscript received : 14 Juni 2016 Revision accepted: 15 Agustus 2016

\begin{abstract}
This study aims to improving critical thinking skills of student of class XI MIA 1 SMA Negeri 6 Surakarta in the academic year 2015/2016 through the implementation of Constructivist-Metacogitive model. This research considered as Classroom Action Research that performed whitin 2 cycles and consist of 4 steps namely planning, action, observation, and reflection. The research procedure refers to Kemmis-Mc.Taggart spiral technique. Data are obtained by questionnaire, essay test, interview, and documentation. Data analysis using qualitative descriptive technique. The main data regarding students' critical thinking skills covering several aspects, namely the interpretation, analysis, evaluation, inference, explanation and self-regulation was measured using a test arranged by the researcher. Data analysis using descriptive analysis technique. Data validation using triangulation techniques. The average yield of pre-cycle critical thinking skills is $33.71 \%$ (low), then increased to $47.6 \%$ (average) at the first cycle, and increased to $75.76 \%$ (high) at the second cycle. The student's critical thingking skill improvement have reached the reseach target $(\geq 20 \%)$, Thus, application of constructivist-metacognitive models can improve students' critical thinking skills. The results showed that the application of Constructivist Model-metacognitive improving critical thinking skills of the students of class XI MIA 1 SMA Negeri 6 Surakarta.
\end{abstract}

Keywords: Constructivis-metacognitive models, Critical Thinking Skills, Coordination System.

\section{PENDAHULUAN}

Pendidikan berperan penting dalam kemajuan bangsa. Pendidikan harus dikembangkan secara terus menerus sesuai dengan perkembangan zaman. Melalui pendidikan, bangsa Indonesia dapat meningkatkan kualitas sumber daya manusia. Pendidikan nasional bertujuan meningkatkan sumber daya manusia yang beriman, bertaqwa, berbudi pekerti, berdisiplin, bertanggung jawab, mandiri, dan cerdas.

Pembelajaran pada abad ke-21 mengharuskan siswa mempunyai keterampilan berpikir yang biasa dikenal dengan HOTS (High Order Thinking and Skill). Era pengetahuan pada abad 21 menuntut pendidikan untuk mempersiapkan siswa menghadapi persaingan dalam ekonomi global. Partnership for $21^{\text {st }}$ Century Skills (P21) menekankan pada inti pembelajaran abad 21 yang mengharuskan siswa memiliki kompetensi penting berupa kemampuan berpikir kritis, pemecahan masalah, komunikasi dan kolaborasi (P21, 2009).

Proses pembelajaran di kelas lebih banyak didominasi kepada kegiatan siswa untuk menghafal informasi. Disisi lain, kemampuan berpikir tingkat tinggi merupakan kemampuan yang sangat penting bagi setiap orang yang digunakan untuk memecahkan masalah kehidupan dengan berpikir serius, aktif, teliti dalam menganalisis semua informasi yang mereka terima dengan menyertakan alasan yang rasional sehingga setiap tindakan yang akan dilakukan adalah benar (Irham, 2014). Oleh karena itu, pengembangan kemampuan berpikir tingkat tinggi menjadi sangat penting bagi siswa di setiap jenjang pendidikan.

Berpikir kritis merupakan bagian dari kemampuan berpikir tingkat tinggi yang sangat esensial bagi kehidupan dan pekerjaan (Oka, 2010). Kemampuan berpikir kritis juga menjadi sarana untuk mencapai tujuan pendidikan yaitu agar siswa mampu memecahkan masalah taraf tinggi (Nasution, 2008). 
Observasi awal terhadap pembelajaran yang dilakukan pada tanggal 2 Desember 2015 di SMA Negeri 6 Surakarta menunjukkan bahwa guru lebih banyak menjelaskan materi dengan metode ceramah (teacher center) dan siswa cenderung memperhatikan dan mencatat hal-hal yang disampaikan guru selama pembelajaran. Selama pembelajaran, siswa bertanya dengan pertanyaan kategori menghafal dan mengulang materi yang dijelaskan oleh guru. Interaksi pembelajaran hanya terjadi antara guru dengan siswa saja, sedangkan interaksi pembelajaran antar siswa tidak terlihat selama pembelajaran. Hal ini ditunjukkan ketika beberapa siswa mengajukan pertanyaan dan langsung dijawab oleh guru tanpa memberi kesempatan siswa lain untuk menjawab. Referensi yang digunakan siswa masih kurang, siswa hanya terpaku pada buku lks saja tanpa sumber belajar lainnya. Saat berdiskusi, banyak siswa yang tidak bekerja dan merasa kesulitan untuk berpikir mengenai pemecahan masalah yang diberikan.

Observasi kedua dilakukan pada tanggal 11 Februari 2016. Observasi ini dilakukan sebagai tindak lanjut terhadap hasi observasi awal di kelas XI MIA 1 melalui pengamatan langsung. Hasil observasi menunjukkan bahwa persentase siswa yang bertanya mengenai materi yang belum dipahami sebesar $12,12 \%$. Siswa memberikan penjelasan atas pertanyaan yang diberikan guru disertai pendapat yang logis atau referensi yang mendukung sebesar $9,09 \%$. Siswa memberikan penjelasan atas pertanyaan yang diberikan guru tanpa disertai pendapat yang logis dan referensi yang mendukung sebesar $30,30 \%$. Pada kegiatan diskusi, baik kelompok maupun kelas, siswa mendiskusikan masalah yang dihadapi dalam kegiatan belajar mengajar sebesar 24,20\%. Siswa mengemukakan hasil diskusi dan menghubungkannya dengan teori sebesar $15,15 \%$. Siswa memberikan penilaian terhadap siswa lain yang telah mengemukakan pendapat sebesar 3,03\%. Hal ini diperkuat dengan hasil wawancara dengan siswa yang menunjukkan bahwa siswa merasa kesulitan dalam mempelajari Biologi, siswa kurang dilibatkan dalam penemuan konsep, menganalisis permasalahan dan menyimpulkan pembelajaran. Dari permasalahan di atas secara garis besar menunjukkan bahwa siswa kurang memberdayakan kemampuan berpikirnya, sehingga dapat dikatakan bahwa kemampuan berpikir kritis siswa masih rendah.

Observasi ketiga dilakukan pada tanggal 12 Februari 2016. Observasi ini dilakukan sebagai tindak lanjut terhadap hasil observasi kedua di kelas XI MIA 1 melalui pemberian soal berpikir kritis. Hasil analisis kemampuan berpikir kritis siswa di SMA Negeri 6 Surakarta dengan rincian sebagai berikut, a) aspek menginterpretasi kurang baik yaitu sebesar $38,38 \%$, b) aspek menganalisis kurang baik yaitu sebesar 21,20\%, c) aspek mengevaluasi kurang baik yaitu sebesar $37,12 \%$, d) aspek menginferensi kurang baik yaitu sebesar $21,19 \%$, e) aspek menjelaskan kurang baik yaitu sebesar 28,03\% dan f) aspek meregulasi diri kurang baik yaitu sebesar $38,25 \%$. Hasil observasi diperkuat dengan wawancara terhadap guru dan siswa menunjukkan bahwa siswa mempunyai kecenderungan dapat mengerjakan soal yang bersifat mengingat kembali, memahami, menjelaskan, dan mengaplikasikan. Namun, masih banyak siswa kesulitan dalam menjawab soal yang bersifat menganalisis, mengevaluasi serta merumuskan hipotesis. Observasi tersebut memperlihatkan bahwa siswa lemah dalam mengerjakan soal kategori $\mathrm{C}_{4}-\mathrm{C}_{6}$. Hasil analisis tersebut merujuk pada kurangnya kemampuan berpikir kritis siswa. Kemampuan berpikir kritis siswa dapat dikatakan rendah apabila persentase dari masing-masing aspek yang diperoleh menunjukkan angka kurang dari atau sama dengan 40\% (Arikunto, 2012).

Kemampuan berpikir kritis siswa yang rendah dikarenakan kegiatan pembelajaran kurang memfasilitasi siswa untuk belajar secara aktif. Belajar secara aktif salah satunya dengan berdiskusi. Diskusi kelompok yang dilakukan selama proses pembelajaran mampu meningkatkan kerjasama antar siswa. Kerjasama di dalam kelompok yang baik, mampu membantu seseorang memisahkan antara fakta dan opini, serta menarik kesimpulan dari suatu masalah dengan akurat. Masalah yang nyata terjadi karena adanya perubahan cara hidup orang yang perlu dipikirkan secara kritis sehingga di dalam pembelajaran perlu peningkatan kemampuan berpikir kritis (Khalid, 2011).

Ennis (1993) berpendapat bahwa berpikir kritis merupakan kemampuan berpikir tingkat tinggi yang menuntut siswa mampu membuat keputusan, menganalisis asumsi-asumsi, dan memecahkan masalah. Pemecahan masalah yang melibatkan berpikir kritis dalam pembelajaran Biologi dapat difasilitasi melalui aktivitas yang menuntut siswa mengkonstruksi pikirannya sendiri.

Kemampuan berpikir kritis dapat dikembangkan dalam pembelajaran biologi secara langsung maupun tidak langsung. Pembelajaran biologi yang diarahkan pada pembelajaran konstruktivis yang membentuk pembelajaran yang penuh makna tidak dapat berlangsung dengan baik tanpa keterlibatan siswa untuk berpikir kritis. Sehingga guru harus pandai menentukan teknik, strategi, cara, pendekatan, metode dan model pembelajaran yang dapat mengembangkan tingkat kemampuan berpikir kritis siswa. 
Model pembelajaran yang berpotensi untuk meningkatkan kemampuan berpikir kritis siswa XI MIA 1 salah satunya adalah Model KonstruktivisMetakognitif. Model Konstruktivis-Metakognitif merupakan salah satu alternatif baru dalam pembelajaran biologi. Model pembelajaran tersebut menuntut siswa mampu merumuskan hipotesis, menguji hipotesis, memanipulasi objek, memecahkan masalah, berdialog, meneliti, mencari jawaban, mengekspresikan gagasan, mengungkap pertanyaan dan mengadakan refleksi (Prayitno, dkk., 2014). Model pembelajaran konstruktivis-metakognitif berpotensi mampu memberdayakan kapasitas berpikir siswa.

Model Konstruktivis-Metakognitif merupakan model pembelajaran yang berorientasi pada pembelajaran yang memberdayakan kemampuan berpikir dan kemandirian belajar siswa. Menurut Prayitno (2014), model pembelajaran konstruktivismetakognitif mampu melatih kemampuan berpikir kritis siswa karena model pembelajaran ini menuntut siswa untuk belajar mengkonstruksi sebuah konsep melalui suatu proses asimilasi dan akomodasi melalui kegiatan diskusi dan eksperimen. Model pembelajaran ini dikembangkan secara integratif antara model pembelajaran yang berbasis konstruktivis dan berbasis metakognitif. Pembelajaran berbasis konstruktivis berpotensi mampu memberdayakan kemampuan berpikir siswa sedangkan pembelajaran metakognitif berpotensi melatihkan kemandirian belajar siswa. Model pembelajaran tersebut mempunyai karakteristik konstruktivis dan metakognitif yang saling komplementer. Penerapan model pembelajaran konstruktivis-metakognitif secara parsial kurang efektif memberdayakan kemampuan berpikir dan kemandirian belajar siswa. Misalnya, penerapan konstruktivis tanpa metakognitif akan menyebabkan kemandirian belajar siswa kurang optimal dan sebaliknya, penerapan metakognitif tanpa konstruktivis dinilai kurang memberdayakan kemampuan berpikir siswa.

Kelebihan model pembelajaran Kontruktivismetakognitif yaitu model ini dirancang untuk memberdayakan keterampilan berpikir siswa, salah satunya yaitu keterampilan metakognisi. Konstruktivis menuntut siswa menemukan dan mengkonstruksi sendiri pengetahuan. Kegiatan menemukan dan mengkonstruksi pengetahuan akan menghantarkan siswa mengetahui posisi kognisinya dalam mengkonstruksi pengetahuan, akibatnya keterampilan metakognisi siswa dapat terberdayakan melalui kegiatan refleksi diri, merencanakan kembali, memantau ulang, dan mengevaluasi kembali kegiatan belajarnya. Pembentukan kelompok kolaboratif didalam kelas menyebabkan siswa memiliki tanggungjawab yang lebih untuk nilai kelompok, siswa dalam kelompok akan bekerja sama untuk mencapai pemahaman yang sama dalam fase pengkonstruksian konsep.

Sistem koordinasi merupakan salah satu pokok bahasan pada pelajaran Biologi SMA kelas XI yang mempunyai karakteristik yang abstrak dan rumit. Hal ini dikarenakan materi tersebut mempelajari tentang mekanisme fisika dan kimiawi yang komplek. Materi sistem koordinasi mempunyai empat prinsip penting yaitu: mekanisme sebab akibat, hubungan antara struktur dan fungsi, aliran informasi dan homeostatis. Sehingga dalam mempelajari materi tersebut, siswa membutuhkan kemampuan berpikir kritis untuk memperdalam konsep-konsep yang abstrak. Siswa diharapkan mampu mengkonstruksi konsep melalui proses asimilasi dan akomodasi melalui kegiatan diskusi dan eksperimen dengan penerapan model pembelajaran konstruktivis-metakognitif.

Berdasarkan uraian tersebut, perlu dilakukan penelitian dengan judul "Penerapan Model Konstruktivis-Metakognitif pada Materi Sistem Koordinasi untuk Meningkatkan Kemampuan Berpikir Kritis Siswa Kelas XI MIA 1 SMA Negeri 6 Surakarta Tahun Pelajaran 2015/2016"

\section{METODE PENELITIAN}

Penelitian ini dilaksanakan di Sekolah Menengah Atas (SMA) Negeri 6 Surakarta yang terletak di Jl. Mr. Sartono no.30 Surakarta. Sekolah tersebut mempunyai 28 kelas yang terdiri dari 9 kelas $\mathrm{X}, 9$ kelas XI, dan 10 kelas XII. Penelitian ini dilakukan pada kelas XI MIPA 1 semester genap tahun ajaran 2015/2016. Penelitian dilakukan secara bertahap yang secara garis besar dibagi menjadi tiga tahap, yaitu: tahap persiapan, tahap pelaksanaan, dan tahap penyelesaian. Penelitian ini dilakukan mulai bulan Desember 2015 sampai April 2016. Metode penelitian yang digunakan adalah Penelitian Tindakan Kelas (PTK). Penelitian ini bertujuan untuk memecahkan masalah yang timbul dalam kelas, penelitian dilaksanakan dengan berkolaborasi bersama guru bidang studi. Permasalahan kelas pada penelitian ditangani dengan tindakan berupa aplikasi Model Konstruktivis-Metakognitif pada materi Sistem Koordinasi. PTK terdiri dari 4 tahapan dasar yang saling terkait dan berkesinambungan, yaitu perencanaan (planning), pelaksanaan (acting), pengamatan (observing) dan refleksi (reflecting). Tindakan yang berulang artinya yang berlangsung pada semua siklus pada pokok bahasan sistem koordinasi diterapkan tindakan yang sama, yakni penerapan model pembelajaran KonstruktivisMetakognitif. Sebelum pelaksanaan tindakan didahului oleh Pratindakan (Prasiklus) untuk mengetahui keadaan awal proses pembelajaran. 
Data yang dikumpulkan dalam penelitian penerapan Model Konstruktivis-Metakognitif berupa data primer dan data sekunder. Data primer yang dikumpulkan merupakan data hasil tes kemampuan berpikir kritis siswa dengan aspek meliputi interpretasi, analisis, evaluasi, inferensi, penjelasan dan regulasi diri yang disusun peneliti kemudian dikerjakan secara mandiri oleh siswa sebagai sumber primer. Data sekunder berupa hasil pengamatan menggunakan Lembar Observasi yang dilakukan oleh observer partisipan, wawancara terkait dengan sikap siswa yang mencerminkan kemampuan berpikir kritisnya dengan guru sebagai narasumber, dan dokumen berupa hasil belajar siswa sebelum dilakukan tindakan, hasil pekerjaan lembar kerja siswa dan foto selama kegiatan pembelajaran berlangsung.

Teknik yang digunakan untuk mengumpulkan data peningkatan kemampuan berpikir kritis meliputi teknik tes dengan tes essay dan teknik non tes dengan lembar observasi, wawancara, dan metode dokumentasi. Teknis analisis yang digunakan dalam penelitian adalah deskriptif kualitatif berdasarkan hasil observasi dan refleksi dari tiap-tiap siklus. Prosedur dan langkah-langkah dalam penelitian tindakan kelas ini mengikuti model yang dikembangkan oleh Kemmis dan Mc. Taggart yang berupa model spiral yaitu dalam satu siklus terdiri dari tahap perencanaan, tindakan, observasi dan refleksi (Arikunto, dkk., 2011). Indikator ketercapaian dari penelitian ini yakni peningkatan persentase sebesar > $20 \%$

\section{HASIL DAN PEMBAHASAN}

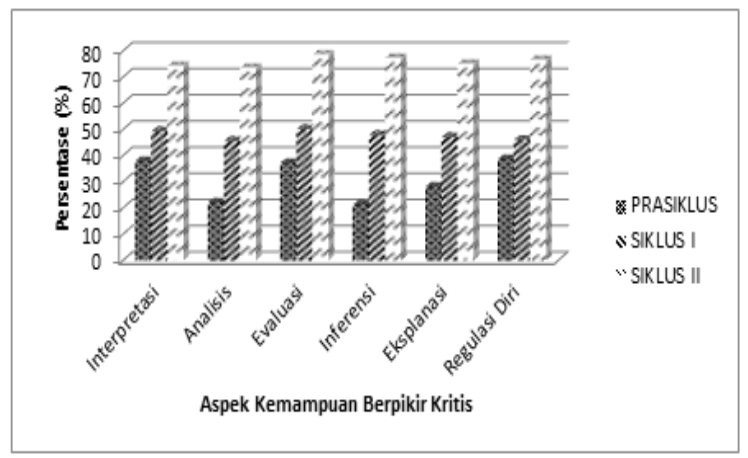

Gambar 1. Diagram Perbandingan Aspek Kemampuan Berpikir Kritis Berdasarkan Tes Prasiklus, Siklus I dan Siklus II

Berdasarkan Gambar 1 terdapat peningkatan yang berbeda-beda untuk setiap aspek kemampuan berpikir kritis dari siklus pertama hingga siklus kedua.
Persentase capaian aspek kemampuan berpikir kritis pada prasiklus yaitu aspek interpretasi (interpretation) sebesar 37,88\% dengan kategori rendah, analisis (analysis) sebesar 21,97\% dengan kategori rendah, evaluasi (evaluation) sebesar 37,12\% dengan kategori rendah, kesimpulan (inference) sebesar 21,21\% dengan kategori rendah, penjelasan (explanation) sebesar 28,03\% dengan kategori rendah dan pengaturan diri (self-regulation) sebesar 38,64\% dengan kategori rendah. Seluruh aspek kemampuan berpikir kritis pada Prasiklus termasuk kategori rendah.

Persentase capaian aspek kemampuan berpikir kritis pada Siklus I yaitu aspek interpretasi (interpretation) sebesar 49,24\% dengan karetogi sedang, analisis (analysis) sebesar 45,45\% dengan kategori sedang, evaluasi (evaluation) sebesar 50,00\% dengan kategori sedang, kesimpulan (inference) sebesar $47,73 \%$ dengan kategori sedang, penjelasan (explanation) sebesar 46,97\% dengan kategori sedang dan pengaturan diri (self-regulation) sebesar 46,21\% dengan kategori sedang.

Persentasi capaian aspek kemampuan berpikir kritis pada siklus II yaitu aspek interpretasi (interpretation) sebesar 74,24\% dengan kategori tinggi, analisis (analysis) sebesar 73,48\% dengan kategori tinggi, evaluasi (evaluation) sebesar 78,03\% dengan kategori tinggi, kesimpulan (inference) sebesar $77,27 \%$ dengan kategori tinggi, penjelasan (explanation) sebesar $75,00 \%$ dengan kategori tinggi dan pengaturan diri (self-regulation) sebesar 76,52\% dengan kategori tinggi. Seluruh aspek kemampuan berpikir kritis pada Siklus II termasuk kategori tinggi. Kenaikan persentase capaian aspek kemampuan berpikir kritis dari Siklus I dan Siklus II dapat dilihat pada Tabel 1.

Tabel 1. Total Persentase Peningkatan Capaian Aspek Kemampuan Berpikir Kritis

\begin{tabular}{lccccl}
\hline \multirow{2}{*}{ Aspek } & \multicolumn{3}{c}{ Peningkatan (\%) } & Targ & Ket. \\
\cline { 2 - 4 } & $\begin{array}{c}\text { Siklu } \\
\text { et I }\end{array}$ & $\begin{array}{c}\text { Siklu } \\
\text { s II }\end{array}$ & Total & \\
$(\%)$ & \\
\hline $\begin{array}{l}\text { Interpret } \\
\text { asi }\end{array}$ & 11,36 & 25,00 & 36,36 & $\geq 20$ & Tercapai \\
Analisis & 23,48 & 28,03 & 51,51 & $\geq 20$ & Tercapai \\
$\begin{array}{l}\text { Evaluasi } \\
\text { Kesimp }\end{array}$ & 12,88 & 28,03 & 41,36 & $\geq 20$ & Tercapai \\
ulan & 26,52 & 29,54 & 56,05 & $\geq 20$ & Tercapai \\
$\begin{array}{l}\text { Penjelas } \\
\text { an }\end{array}$ & 18,94 & 28,03 & 46,97 & $\geq 20$ & Tercapai \\
$\begin{array}{l}\text { Pengatu } \\
\text { ran Diri }\end{array}$ & 7,36 & 30,31 & 37,88 & $\geq 20$ & Tercapai \\
\hline
\end{tabular}




\begin{tabular}{llll}
\hline Rata- & 16,76 & 28,16 & 45,02 \\
ta
\end{tabular}

Tabel 1 menunjukkan peningkatan dari Siklus I sampai Siklus II aspek menginterpretasi sebesar $25,00 \%$, aspek menganalisis sebesar $28,03 \%$, aspek mengevaluasi sebesar $28,03 \%$, aspek menyimpulkan sebesar 29,54\%, aspek menjelaskan sebesar 28,03\% dan aspek pengaturan diri sebesar 30,31\%. Aspek yang mengalami peningkatan tertnggi adalah aspek pengaturan diri. Aspek yang mengalami peningkatan terendah adalah aspek interpretasi. Data persentase capaian dari Siklus I ke Siklus II menunjukkan semua aspek kemampuan berpikir kritis mengalami peningkatan.

Total peningkatan dari Prasiklus hingga Siklus 2 aspek menginterpretasi sebesar 36,36\%, aspek menganalisis sebesar $51,51 \%$, aspek mengevaluasi sebesar 41,36\%, aspek menyimpulkan sebesar $56,06 \%$, aspek menjelaskan sebesar $46,97 \%$ dan aspek pengaturan diri sebesar $37,88 \%$. Aspek yang mengalami peningkatan tertinggi adalah aspek menyimpulkan. Aspek yang mengalami peningkatan terendah adalah aspek menginterpretasi. Berdasarkan total peningkatan capaian dari Prasiklus hingga Siklus II, seluruh aspek telah memenuh target penelitian yaitu $\geq 20$.

Peningkatan kemampuan berpikir kritis tersebut juga didukung oleh peningkatan hasil wawancara dengan guru dan siswa, juga pengamatan yang dilakukan oleh observer. Hasil wawancara menunjukan pendapat siswa yang mengalami kemajuan dalam cara menyampaikan pendapat, pemahaman materi, cara bertanya dengan benar, menjelaskan materi kepada teman, berani mengajukan pertanyaan, dan mengevaluasi materi. Kemajuan siswa tersebut menunjukan telah berjalannya kemampuan berpikir tingkat tinggi siswa yang salah satunya adalah kemampuan berpikir kritis.

Tindakan Model Konstruktivis-metakognitif dalam penelitian ini mampu meningkatkan kemampuan berpikir kritis siswa dari $30,81 \%$ pada prasiklus menjadi $75,76 \%$ pada siklus II. Kemampuan berpikir kritis merupakan kemampuan berpikir tingkat tinggi untuk membantu siswa dalam membuat keputusan, menganalisis asumsi-asumsi, dan memecahkan masalah. Pemecahan masalah yang melibatkan berpikir kritis dalam pembelajaran Biologi dapat teratasi dengan baik melalui pengalaman langsung sehingga siswa dituntut untuk mengkonstruksi pikirannya sendiri (Ennis, 1993). Sadia (2008) mengemukakan bahwa berpikir kritis tidak dapat diajarkan melalui metode ceramah, karena berpikir kritis merupakan proses aktif. Kemampuan intelektual dari berpikir kritis mencakup berpikir analitis, berpikir sintesis, berpikir reflektif dan sebagainya harus dipelajari melalui aktualisasi penampilan (performance). Berpikir kritis dapat diajarkan melalui kegiatan laboratorium penemuan, pekerjaan rumah yang dapat mengembangkan kemampuan berpikir kritis, dan ujian yang dirancang untuk membangun kemampuan berpikir kritis. Hasil observasi penerapan Model Konstruktivis-metakogitif menunjukkan siswa menjadi lebih aktif dalam mencari sumber informasi untuk belajar. Hal ini terjadi karena kegiatan diskusi siswa baik secara langsung maupun tidak langsung menjadi lebih interaktif, siswa dapat saling memberikan analisa dengan argumen yang diperolehnya dari berbagai sumber. Interaksi yang terjadi ini dapat mengembangkan kemampuan berpikir kritis siswa.

Model konstruktivis-metakognitif terdiri dari pembentukan kelompok kolaboratif, aktivasi skemata awal, menciptakan konflik kognitif, perencanaan pengkonstruksian konsep, pengonstruksian, pemantauan dan evaluasi konsep, presentasi kelas, tes individu dan rekognisi tim. Sintaks-sintaks ini memfasilitasi siswa untuk aktif dalam pembelajaran dan memacu siswa untuk berpikir tingkat tinggi, khususnya berpikir kritis untuk menemukan suatu konsep pembelajaran. Hal ini sesuai dengan hasil penelitian Hotimah (2009) yang meneliti tentang kemampuan berpikir kritis siswa dengan model berbasis konstruktivis lebih aktif pada kegiatan pembelajaran dibandingkan dengan penggunaan model konvensional. Penggunaan Model Konstruktivis-metakognitif sesuai dengan teori belajar kognitif Piaget dan Vygotsky, serta pandangan metakognitif Flavell. Piaget berpendapat bahwa belajar tidak hanya melibatkan stimulus dan respon, namun melibatkan proses berpikir yang sangat kompleks (Schunk, 2012). Pembelajaran konstruktivis menuntut siswa untuk mengonstruksi pengetahuannya secara mandiri (Khalid \& Azeem, 2012; Kalpana, 2014). Teori konstruktivis memfasilitasi siswa dalam menciptakan pembelajarannya sendiri (Schunk, 2012), sehingga siswa dituntut untuk bertanggung jawab atas semua kegiatan belajarnya (Irham \& Wiyani, 2014). Karakter konstruktivis pada model pembelajaran tersebut mampu mengasah kemampuan berpikir kritis dan meningkatkan penguasaan potensi sains siswa. Karakter metakognitif pada model pembelajaran tersebut menuntut siswa mampu mengontrol aktivitas belajarnya sehingga siswa terampil dalam melakukan perencanaan, memanajemen, memonitor, merevisi dan mengevaluasi pembelajaran (Prayitno, dkk., 2014).

Pada pembelajaran konstruktivis-metakognitif, siswa yang terlibat aktif dalam eksperimen dan pembelajaran akan lebih mudah meningkatkan kemampuan berpikir kritisnya. Guru memberikan suatu fenomena yang dapat mengundang siswa untuk 
mengajukan pertanyaan dan membuat hipotesis melalui proses berpikir (Bilgin,2009). Siswa yang diberi perlakuan belajar dengan berdiskusi mempunyai tingkat berpikir kritis tinggi daripada siswa yang belajar secara individual (De Bono, 2007). Oleh sebab itu, nilai kemampuan berpikir kritis siswa yang belajar dengan model pembelajaran konstruktivis-metakognitif lebih tinggi daripada siswa yang belajar dengan model pembelajaran konvensional.

Interpretasi dapat diartikan sebagai kegiatan mengelompokkan, menyamakan dan menjelaskan makna (Facione,2013). Pada siklus pertama tentang materi Sistem Saraf pada tahapan apersepsi dan observasi ketercapaian aspek Interpretasi masih sedang yaitu 49,24\% akan tetapi belum memenuhi target penelitian. Siswa belum terbiasa membaca tabel dan menganalisa tabel menjadi sebuah data yang baik. Peningkatan terjadi pada siklus kedua, kemampuan berpikir kritis siswa pada aspek interpretasi meningkat menjadi 74,24\% dengan kategori tinggi. Peningkatan pada siklus II terjadi karena siswa sudah terlatih untuk melakukan sebuah eksperimen secara runtut dan sistematis, serta menuliskan data dalam tabel dengan benar. Pada siklus I, aspek interpretasi masih tergolong sedang. Hal ini ditunjukkan bahwa siswa telah mampu meringkas deskripsi dari pola keterkaitan antar informasi. Sedangkan pada siklus II, aspek interpretasi sudah tergolong tinggi. Hal ini ditunjukkan bahwa siswa telah mampu meringkas dan mengeksplorasi pola keterkaitan dalam sebuah informasi yang diterima (Facione,2013).

Tahapan dari Model Konstruktivis-Metakognitif diduga dapat melatih siswa dalam mengembangkan kemampuan berpikir kritis, yaitu aspek interpretasi. Siswa mampu mengelompokkan permasalahan atau fenomena yang diterima, sehingga mempunyai makna yang jelas. Diskusi yang aktif dapat meningkatkan kemampuan berpikir kritis seperti identifikasi masalah, kategorisasi, klasifikasi dan interpretasi (Jacobsen, 2009). Hal ini sejalan dengan teori belajar konstruktivis Piaget yang menyatakan bahwa proses aktif dalam belajar akan membuat siswa membangun pemahaman mengenai fakta melalui pengalaman belajarnya (Trianto, 2013).

Analisis dapat diartikan sebagai kegiatan mengenali pendapat, menguji ide-ide dan mengenali alasan dan pernyataan (Facione,2013). Pada siklus pertama ketercapaian aspek analisis masih sedang yaitu $45,45 \%$ akan tetapi sudah memenuhi target penelitian. Siswa mampu mengkategorisasikan informasi dalam kelompok yang tepat (Facione, 2013). Peningkatan terjadi pada siklus kedua, kemampuan berpikir kritis siswa pada aspek analisis meningkat menjadi $73,48 \%$ dengan kategori tinggi.
Peningkatan pada siklus II terjadi karena siswa telah mampu mengeksplorasi pengkategorisasian informasi yang didapat (Facione, 2013).

Aspek analisis diperoleh melalui identifikasi masalah sehingga memperoleh konsep dan deskripsi serta pengajuan opini melalui pengalaman belajarnya (Facione, 2013). Hal ini sejalan dengan pendapat Lau (2011) yang menyebutkan bahwa melalui aktivitas mengumpulkan data, membuat diagram, mengidentifikasi foto atau gambar, membuka dan memahami referensi internet yang relevan secara mandiri akan meningkatkan kemampuan berpikir kritis.

Menurut Rusman (2012), kemampuan berpikir kritis akan timbul ketika siswa menganalisis permasalahan atau hasil percobaan dengan mencari bukti untuk mendukung gagasannya dan dapat mengaitkan informasi yang telah diperoleh ketika seseorang belajar dengan pengetahuan yang telah dimiliki sebelumnya, sehingga pembelajaran tersebut akan lebih bermakna sesuai dengan teori belajar Ausubel. Menurut Vygotsky, interaksi sosial dengan teman lain akan membantu terbentuknya ide baru dan memperluas pengetahuan intelektual seseorang. Pada tahap ini seseorang dapat mengembangkan kemampuan berpikir kritisnya melalui aspek analisis (Rusman, 2012).

Evaluasi dapat diartikan sebagai kegiatan menilai kredibilitas pernyataan dengan menggambarkan persepsi seseorang (Facione,2013). Pada siklus pertama ketercapaian aspek evaluasi masih sedang yaitu $50,00 \%$ akan tetapi belum memenuhi target penelitian. Siswa mampu menilai pernyataan yang diungkapkan (Facione, 2013). Peningkatan terjadi pada siklus kedua, kemampuan berpikir kritis siswa pada aspek evaluasi meningkat menjadi 78,03\% dengan kategori tinggi. Peningkatan pada siklus II terjadi karena siswa telah mampu menjelaskan alasan mengenai solusi terbaik untuk suatu permasalahan dengan pertimbangan yang matang (Facione, 2013).

Pada pertemuan pertama siklus I masih terdapat siswa yang kurang bisa memberikan hipotesis karena informasi yang digunakan bersumber dari satu buku saja, sedangkan pada siklus kedua siswa mulai memanfaatkan beberapa buku paket dan sumber belajar lain seperti internet untuk menjawab jawaban LKS tentang indera serta membantu meahami hasil percobaan yang dilakukan. Siswa sudah terbiasa dengan berdiskusi kelompok dan saling bertukar pikiran. Jawaban setiap kelompok dapat berbedabeda, namun siswa selalu mencari sumber referensi yang relevan untuk mengetahui mana jawaban yang dianggap tepat. 
Kemampuan mengevaluasi dilatihkan pada siswa melalui kegiatan diskusi saat pengkonstruksian konsep, presentasi dan dilatihkan kembali pada saat tes individual. Perbedaannya terletak pada fase pengkonstruksian konsep mengedepankan evaluasi bersama dengan tim, akan tetapi pada saat tes individual lebih menekankan pada kemampuan mengevaluasi secara mandiri. Pada saat presentasi kelas, siswa dapat saling menanggapi pernyataan temannya, memberikan alternatif jawaban yang lain dan mengevaluasi sumber informasi pada saat berdiskusi. Tahap ini memberikan banyak kesempatan kepada siswa untuk menyampaikan pendapat, meminta pendapat dan memproses umpan balik mengenai jawaban pertanyaan. Adanya saran dari hasil presentasi pada tahap ini akan memungkinkan siswa untuk mengembangkan kemampuan berpikir kritis pada aspek evaluasi (Heidare,Poor,\& Poor, 2011)

Inferensi dapat diartikan sebagai kegiatan mengidentifikasi dan memilih unsur-unsur yang diperlukan untuk membentuk kesimpulan yang beralasan (Facione,2013). Pada siklus pertama ketercapaian aspek inferensi masih sedang yaitu 47,73\% akan tetapi sudah memenuhi target penelitian. Siswa mampu membuat kesimpulan dari informasi yang telah diperoleh (Facione, 2013). Peningkatan terjadi pada siklus kedua, kemampuan berpikir kritis siswa pada aspek inferensi meningkat menjadi $77,27 \%$ dengan kategori tinggi. Peningkatan pada siklus II terjadi karena siswa telah mampu membuat kesimpulan disertai referensi pendukung yang tepat berdasarkan informasi yang telah diperoleh (Facione, 2013).

Siswa sudah mulai terampil dalam mengolah informasi yang diperoleh untuk kemudian diambil kesimpulan. Kemampuan berpikir kritis siswa dapat meningkat dengan melibatkan siswa dalam membuktikan suatu pernyataan, memecahkan masalah dan menarik kesimpulan (Kalpana, 2014).

Eksplanasi dapat diartikan sebagai kegiatan membenarkan bahwa suatu alasan berdasar bukti dan kegiatan untuk mempresentasikan alasan seseorang berupa argumentasi yang meyakinkan (Facione,2013). Pada siklus pertama ketercapaian aspek eksplanasi masih sedang yaitu $46,97 \%$ akan tetapi belum memenuhi target penelitian. Siswa mampu membenarkan suatu alasan berdasarkan bukti yang ditemukan (Facione, 2013). Peningkatan terjadi pada siklus kedua, kemampuan berpikir kritis siswa pada aspek eksplanasi meningkat menjadi $75,00 \%$ dengan kategori tinggi. Peningkatan pada siklus II terjadi karena siswa telah mampu membenarkan suatu alasan berdasarkan bukti yang ditemukan dan dapat memberikan argumentasi yang meyakinkan (Facione, 2013).
Kemampuan menjelaskan dapat dilatihkan pada saat fase presentasi kelas. Pada tahap presentasi kelas, siswa bertindak sebagai presentator yang bertugas menjelaskan hasil pengkonstruksian konsep di tahap sebelumnya. Kemudian siswa dapat saling menanggapi pernyataan temannya, memberikan alternatif jawaban yang lain dan mengevaluasi sumber informasi pada saat berdiskusi. Pada tahap ini, siswa diberikan banyak kesempatan untuk menyampaikan pendapat, meminta pendapat dan memproses umpan balik mengenai jawaban pertanyaan. Kemampuan menjelaskan pada siswa yang baik akan terlihat ketika siswa tersebut menyampaikan pendapat atau gagasannya dengan penuh rasa percaya diri (Johnson, 2010).

Regulasi diri dapat diartikan sebagai kesadaran seseorang untuk memonitor proses berpikirnya dengan mengaplikasikan keterampilan dalam menganalisis dan mengevaluasi kemampuan diri dalam mengambil kesimpulan dengan bentuk pertanyaan, konfirmasi atau koreksi (Facione,2013). Pada siklus pertama ketercapaian aspek regulasi diri masih sedang yaitu $46,21 \%$ akan tetapi belum memenuhi target penelitian. Siswa mampu memonitor proses berpikirnya (Facione, 2013). Peningkatan terjadi pada siklus kedua, kemampuan berpikir kritis siswa pada aspek regulasi diri meningkat menjadi $76,52 \%$ dengan kategori tinggi. Peningkatan pada siklus II terjadi karena siswa telah mampu untuk mengeksplorasi kesalahan dan kelemahan diri sendiri (Facione, 2013).

Model yang berbasis metakognitif membuat siswa mampu mengendalikan aktivitas belajar secara mandiri (Moore, 2004). Siswa yang mempunyai pengaturan diri yang baik adalah siswa yang memiliki pengetahuan tentang strategi belajar efektif dan bagaimana serta kapan menggunakan pengetahuan tersebut. Teori konstruktivis mendasari siswa harus membangun pengetahuan dalam benaknya sendiri. Pengaturan diri dapat muncul karena adanya kepercayaan diri. Kepercayaan diri (self efficacy) dapat menimbulkan self regulation, self monitoring, dan self evaluation (Zimmerman, 2000). Para pemikir kritis juga memiliki kecakapan metakognisi yaitu berpikir tentang pemikirannya sendiri (Fisher, 2009)

\section{SIMPULAN DAN SARAN}

Berdasarkan hasil penelitian dapat disimpulkan bahwa model Konstruktivis-metakognitif pada pokok bahsan Sistem Koordinasi dapat meningkatkan kemampuan berpikir kritis siswa kelas XI MIA 1 SMA Negeri 6 Surakarta Tahun Pelajaran 2015/2016. Peningkatan aspek berpikir kritis paling optimal pada kemampuan interpretasi siswa. 
Hasil penelitian ini secara teoritis dapat dijadikan sebagai referensi dalam pengembangan penelitian tindakan kelas lebih lanjut dalam rangka meningkatkan kemampuan berpikir kritis.Secara praktis dapat diterapkan pada proses pembelajaran biologi dalam rangka meningkatkan kemampuan berpikir kritis.

\section{DAFTAR PUSTAKA}

Arikunto, S., Suhardjono., \& Supardi. (2011). Penelitian Tindakan Kelas. Jakarta: Bumi Aksara.

Arikunto, Suharsimi. (2012). Dasar-Dasar Evaluasi Pendidikan (Edisi Kedua). Jakarta: Bumi Aksara

Bilgin, I., Senocak, E., \& Mustafa. (2009). The Effects of Problem-Based Learning Instruction on University Students Performance of Conceptual and Quantitative Problems in Gas Concepts, Eurasia Journal of Mathematics Science \& Technology Education, 153164

De Bono, E. (2007). Revolusi Berpikir Edward De Bono. Terj. Ida Sitompul dan Fahmy Yamani. Bandung: Kaifa. (Buku asli diterbitkan 1993)

Ennis, R. H. (1993). Critical Thinking Assessment Theory Into Practice: College of Education, 32 (3), 179-186

Facione, P.A. (2013). Critical Thinking: What It Is and Why It Counts. California : Measured Reason and The California Academic Press.

Fisher, Alec. (2009). Berpikir Kritis Sebuah Pengantar. Jakarta:Erlangga

Heidare, A., Poor, S.B., Poor, F.N. (2011). Effect and Evaluation Of Creativity Instructional Methods On Creativity Of Students. Life Science Journal, 8 (4), 402-408.

Hotimah, N.H. (2009). Optimalisasi Kemampuan Koneksi dan Keaktifan Siswa Melalui Pendekatan Improving Learning Dalam Pembelajara Matematika. PTK. Kelas VIII SMP Negeri 2 Wonosari Klaten Tahun Ajaran 2008/2009, Doctoral dissertation, Universitas Muhammadiyah Surakarta.

Irham, M. \& Wiyani, N. A. (2014). Psikologi Pendidikan: Teori \& Aplikasi dalam Proses Pembelajaran. Yogyakarta: Ar-Ruzz Media.

Jacobsen, D.A., Eggen, \& Kauchak. (2009). Methods For Teaching : Metode-metode Pengajaran Meningkatkan Belajar Siswa TK-SMA Edisi Bahasa Indonesia. Yogyakarta : Pustaka Pelajar

Johnson, E.B. (2010). Contextual Teaching and Learning: Menjadikan Kegiatan Belajar Mengajar Mengasyikkan dan Bermakna. Bandung: Penerbit Kaifa.

Kalpana, T. (2014). A Constructivist Perspective on Teaching and Learning: A Conceptual Framework. International Research Journal of Social Sciences, 3 (1), $27-29$.

Khalid, A. \& Azeem, M. (2012). Constructivist Vs Tradisional: Effective Instructional Approach in Teacher Education. International Journal of Humanities and Social Science, 2 (5), 170 - 177.
Lau, J. Y. F. (2011). An Introduction to Thinking Critically and Creativity: Think More, Think Better. New Jersey: John Wiley \& Sons.

Nasution, S. 2008. Berbagai Pendekatan dalam Proses Belajar dan Mengajar. Jakarta: Bumi Aksara.

Oka, A. A. (2010). Pengaruh Penerapan Belajar Mandiri pada Materi Ekosistem Terhadap Keterampilan Berpikir Kritis dan Kemampuan Memecahkan Masalah Siswa SMA di Kota Metro. Skripsi Tidak Dipublikasikan, Universitas Metro, Lampung.

Partnership for 21st Century Skills. (2009). Framework for 21 st Century Learning.

Prayitno, B. A., Sugiharto, B., \& Sudarisman, S. (2014). Model Pembelajaran Berbasis KonstruktivisMetakognitif. Laporan Penelitian Hibah Tidak Dipublikasikan. FKIP Universitas Sebelas Maret, Surakarta.

Rusman. (2012). Model-Model Pembelajaran: Mengembangkan Propesionalisme Guru Edisi Kedua. Jakarta: Raja Grafindo Persada.

Sadia, I.W. (2008). Model Pembelajaran yang Efektif Untuk Meningkatkan Keterampilan Berpikir Kritis (Suatu Persepsi Guru). Jurnal Pendidikan dan Pengajaran Undiksha, 2(2), 19-237.

Schunk, D. H. (2008). Metacognition, Self-Regulation, and Self-Regulated Learning: Research Recommendations. Educational Psychology Review, 20 (4), 463-467.

Schunk, D. H. (2012). Teori-teori Pembelajaran: Perspektif Pendidikan. Terj. Eva Hamdiah \& Rahmat Fajar. Yogyakarta: Pustaka Pelajar.

Trianto. (2013). Model Pembeajaran Terpadu. Jakarta: Bumi Aksara

Zimmerman, Barry J. (2000). Self Efficacy: An Essential Motive to Learn. New York: Journal Conemporary Educational Psychology, 25, 82-91 